\title{
Green Human Resource Management: A Conceptual Study
}

\author{
Swati Tomer ${ }^{1}$, Dr. Geeta Rana ${ }^{2}$ \\ ${ }^{1}$ Research Scholar, Swami Rama Himalayan University, Jolly Grant, \\ Dehradun, Email: swatitomer06.tomer@gmail.com \\ ${ }^{2}$ Associate Professor, Swami Rama Himalayan University, Jolly Grant, \\ Dehradun, Email: geetaphd@rediffmail.com
}

\begin{abstract}
As we are moving towards industrialization it increases business production, technology and other business activities. Increment in number of industries had given rise to the use of machinery and other heavy equipments - which in turn, used fuels as source of energy, which is the reason for environmental degradation. To save our environment from hazards and to achieve environmental sustainability by adopting green practices it is a high time to become aware about the green concept. The paper tries to explain about Green HR Concept, its importance, its meaning, what are the reasons for greening, ways to make Human Resource functions green and some previous studies on Green HRM conducted by various researchers. The paper will enhance knowledge, awareness, better understanding about the green management idea.
\end{abstract}

Index Terms-Green Human Resource Management, Greening, and Environmental Sustainability

\section{INTRODUCTION}

$\mathrm{G}$ HRM is a novel concept \& is considered a crucial part of HRM. It is a revolutionary concept in the academic world as well as the practical world of HRM (Stojanoska, 2016). The term "Green HRM" was coined by Wehrmeyer in 1996. Majority of people don't know about this concept and those who know they have very less knowledge about it. There are some developments with respect to GHRM concept but they are not related to Indian context. Since Green HRM is considered a new \& emerging field in Management domain \& specifically HRM literature there is need for more research to create deep understanding \& awareness on GHRM.

This paper will solve the purpose of providing a fundamental comprehension of GHRM. In this paper we have attempted to address the following questions:

- What is Green?

- What are the reasons for Greening?

- What is GHRM?

- What is the importance of GHRM?

- What are the ways by which we can make HRM functions Green?

- What are the outcomes of some research studies conducted on Green HRM?

\section{A. Green:-}

'Green' means environmental. Green today has become a buzz word only due to the corporates $\&$ the indi- viduals understanding \& awareness that the consumption levels of resources made by them are higher than what is available. This led to emergence of the concept of "sustainability \& greening".

"Going green" has four major implications regarding HRM- Opatha (2013); \& Opatha \& Arulrajah (2014)

1. Protecting the natural environment.

2. Maintaining the natural environment.

3. Environmental pollution reduction.

4. Creation of natural heritage.

\section{B. Why is Green?}

Govt. \& firms uses natural resources generously for producing various consumer products without thinking about the future generations. Environmental issues like:global warming, environmental pollution, environment degradation is in existence. Due to which the concept of Green Management emerged. Going green means implementing determined life style changes which helps everyone to live in sustainable way. Adopting green practices, green behavior, green actions will help to achieve environmental sustainability and will contribute a positive impact on environment.

\section{Green Human Resource Management}

Concern for the environment already started since 1990s. Organizations, businesses have taken action to reduce waste, pollution by establishing approaches \& system for Environment Management like:- use lesser contaminated materials, product design, reduced packaging \& energy efficient (K.-L. Wong et al., 2013). There were several studies K.-L. Wong; (2013); C.J.C. Jabbour et al. (2012) which have focused on HRM \& Human capital towards environmental sustainability \& environmental concerns. As mentioned by Hussain (2018) Human Resource field plays an important role in chasing green practices, HR plays major role in hiring skilled talents who can implement and adopt green practices in the organization \& can enhance environmental sustainability.

Some of the definitions provided by the scholars of HRM are:-

Wikhamn (2019) stated that "GHRM" is the adoption of HRM practices and strategies which help in achievement of social, financial \& ecological goals, with providing a positive impact to an organization over a longer time horizon. According to (Al Mamun, 2019) GHRM is about 
making the employees green by adopting environmentally-friendly HRM practices, policies so that society, businesses, individual, \& ecology can be benifited by this. Green HRM will shrink the carbon footprint by adopting green initiatives like: electric filing, teleconferencing, recycling, ride sharing, tele-commuting, virtual meetings, e-learning \& paperless offices(M. Mampra; 2013). GHRM practices are very important in order to boost employee morale, providing him job-satisfaction which helps company to achieve better employee engagement, involvement (J. Cherian \& J. Jacob; 2012).

\section{Importance of GHRM}

Subsequent benefits are:-

1. Reduction of climate change concerns.

2. Growth of business firms.

3. To avoid harms to animals.

4. To avoid health diseases caused by pollution.

5. It provides maximum contribution of employee on each of the four roles ie.-:

$>$ Naturalist

$>$ Environmentalist

$>$ Cleaner

$>$ Maker

GHRM is a part of a broader framework of Corporate Social Responsibility which includes application of environmentally-sound strategies \& policies for promoting utilization of natural assets in a sustainable way \& supporting ecology.

\section{MAKING HRM FUNCTIONS GREEN}

HR dept. plays major role in translating green policies into practices as stated by (Renwick, 2008) \& creating renewable environment within the company (Harmon et al, 2010), as a result green goals will help in achieving green missions all over the HR process from entry-exit stage (Dutta, 2012). Developing HRM function green includes adaptation of policies, procedures, which guaran- tee that the organization hires right person at the right time \& at the right place. We tries to seek out to show some ways how to make some major HRM functions green in this paper.

\begin{tabular}{|c|c|}
\hline $\begin{array}{l}\text { Functions of } \\
\text { Human Resource } \\
\text { Management }\end{array}$ & Possible Ways to make HR functions green \\
\hline Staffing & $\begin{array}{l}\text { Assimilation of green values in the recruitment } \\
\text { messages. } \\
\text { Paper less work can be followed by practicing } \\
\text { \& hiring through online means. }\end{array}$ \\
\hline Hiring/ election & $\begin{array}{l}\text { Selecting applicants who have green morals } \\
\text { \& responsibilities towards ecology. } \\
\text { Selecting applicants who practice \& pursue } \\
\text { Green agendas to save environment. }\end{array}$ \\
\hline $\begin{array}{l}\text { Analysis of job/ } \\
\text { job design }\end{array}$ & $\begin{array}{l}\text { Incorporating element of environmental } \\
\text { sustainability in Job Description. } \\
\text { Incorporating Green abilities in Job } \\
\text { Specification. }\end{array}$ \\
\hline Coaching & $\begin{array}{l}\text { Communicating awareness about Green } \\
\text { concept to employees through learning } \\
\text { programs. } \\
\text { Including role analysis \& needs of employees. }\end{array}$ \\
\hline $\begin{array}{l}\text { Measurement of } \\
\text { performance }\end{array}$ & $\begin{array}{l}\text { Evaluating employees' task performance } \\
\text { according to Green-related criteria. } \\
\text { Measuring employees environmental behavior } \\
\text { through key performance indicators. }\end{array}$ \\
\hline $\begin{array}{l}\text { Reward } \\
\text { Management }\end{array}$ & $\begin{array}{l}\text { Providing intrinsic \& extrinsic awards to } \\
\text { employees for their green roles. }\end{array}$ \\
\hline
\end{tabular}

\section{RESEARCH IN GREEN HUMAN RESOURCE}

Following table contains contemporary studies done by various researchers:

\begin{tabular}{|l|l|l|l|l|}
\hline Author & Article Title & HRM Functions & Data Type & Outcomes \\
\hline $\begin{array}{l}\text { Liaquat Ali Rahoo et } \\
\text { al/ 2020/ }\end{array}$ & $\begin{array}{l}\text { Analysis of Green } \\
\text { Human Resource } \\
\text { Practices in IT }\end{array}$ & $\begin{array}{l}\text { Staffing \& selection, } \\
\text { Green performance } \\
\text { measurement, green } \\
\text { Industries of Pakistan } \\
\text { learning \& coaching } \\
\text { programs }\end{array}$ & $\begin{array}{l}\text { Descriptive- survey, } \\
\text { questionnaire }\end{array}$ & $\begin{array}{l}\text { Results revealed that } \\
\text { firms ar not } \\
\text { providing effective } \\
\text { araining programs, not } \\
\text { hiring green } \\
\text { employees \& not } \\
\text { providing results } \\
\text { based performance } \\
\text { system }\end{array}$ \\
\end{tabular}




\begin{tabular}{|c|c|c|c|c|}
\hline Author & Article Title & HRM Functions & Data Type & Outcomes \\
\hline $\begin{array}{lcc}\text { Ibraheem A. } & \text { M. } \\
\text { Aburahma/ } 2020 & \end{array}$ & $\begin{array}{l}\text { The Relationship } \\
\text { between Green HRM } \\
\text { Practices and } \\
\text { Organizational } \\
\text { Performance at Gaza } \\
\text { University }\end{array}$ & $\begin{array}{lr}\text { Green hiring, } & \text { green } \\
\text { instructions, } & \text { green } \\
\text { compensation, } & \text { job } \\
\text { performance, } & \end{array}$ & $\begin{array}{l}\text { Descriptive } \\
\text { quantitative }\end{array}$ & $\begin{array}{l}\text { This study revealed } \\
\text { that there is a positive } \\
\text { relationship between } \\
\text { Green practices and } \\
\text { organizational } \\
\text { objectives }\end{array}$ \\
\hline Aktar \& Islam/2019 & $\begin{array}{l}\text { Green HR strategies } \\
\& \quad \text { Employee } \\
\text { Engagement: } \\
\text { Empirical evidence } \\
\text { from RMG sector }\end{array}$ & $\begin{array}{ll}\text { Green tutoring, green } \\
\text { employee } & \\
\text { involvement, } & \text { green } \\
\text { performance } & \\
\text { appraisals, } & \text { green } \\
\text { incentives } & \end{array}$ & $\begin{array}{l}\text { Descriptive- } \\
\text { questionnaire }\end{array}$ & $\begin{array}{l}\text { Results revealed that } \\
\text { green employee } \\
\text { participation \& green } \\
\text { training } \& \\
\text { development showed } \\
\text { positive relationship } \\
\text { with employee } \\
\text { engagement }\end{array}$ \\
\hline Al Mamum/2019 & $\begin{array}{lr}\text { An Analysis of } \\
\text { Employee Awareness } \\
\text { on GHRM } \\
\text { Evidence } \\
\text { Bangladesh }\end{array}$ & $\begin{array}{l}\text { Personnel planning, } \\
\text { staffing, orientation, } \\
\text { green instructions, } \\
\text { appraisals, reward } \\
\text { management, } \\
\text { employee self-control } \\
\text { management, } \\
\text { employee relations }\end{array}$ & $\begin{array}{l}\text { Combination of both } \\
\text { quantitative } \& \\
\text { qualitative research }\end{array}$ & $\begin{array}{l}\text { Findings of this study } \\
\text { are that majority of } \\
\text { the HR managers } \\
\text { from diff industries } \\
\text { are aware of GHRM. } \\
\text { However, proper } \\
\text { green activities are } \\
\text { not yet practiced in } \\
\text { the organization }\end{array}$ \\
\hline $\begin{array}{l}\text { Reshma Dingra } \& \\
\text { Padmavathy/2019 }\end{array}$ & $\begin{array}{l}\text { GHRM }- \text { A leap } \\
\text { towards sustainability }\end{array}$ & 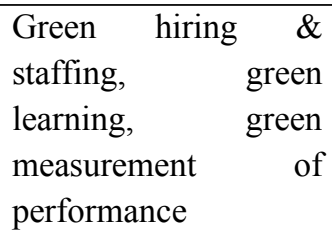 & Case study & $\begin{array}{l}\text { Author suggested } \\
\text { green initiatives for } \\
\text { minimization } \\
\text { environmental } \\
\text { pollution }\end{array}$ \\
\hline $\begin{array}{l}\text { Patil \& Sarode/ } \\
2018\end{array}$ & \begin{tabular}{l}
\multicolumn{2}{l}{ Green HRM : Role of } \\
HR Managers To \\
Achieve \\
environmental \\
sustainability
\end{tabular} & $\begin{array}{lr}\text { green enrollment, } \\
\text { green results } & \text { based } \\
\text { management, } & \text { green } \\
\text { professional } & \\
\text { development, } & \text { green } \\
\text { remunerations } & \text { and } \\
\text { involvement } & \end{array}$ & Systematic Review & $\begin{array}{ll}\text { Study focused } & \text { on } \\
\text { prevention } & \text { of } \\
\text { pollution } & \end{array}$ \\
\hline Tang et al./ 2018 & $\begin{array}{l}\text { Green HR practices: } \\
\text { scale development } \\
\text { and validity }\end{array}$ & $\begin{array}{l}\text { Green staffing, } \\
\text { training \& learning, } \\
\text { green management } \\
\text { for results, green } \\
\text { salary system, } \\
\text { participation }\end{array}$ & $\begin{array}{l}\text { Exploratory analysis } \\
\text { \& factor analysis }\end{array}$ & $\begin{array}{l}\text { Developed a GHRM } \\
\text { scale }\end{array}$ \\
\hline
\end{tabular}




\begin{tabular}{|l|lr|l|l|l|}
\hline Author & Article Title & HRM Functions & Data Type & Outcomes \\
\hline $\begin{array}{l}\text { Seyed Javadin et } \\
\text { al/2017 }\end{array}$ & $\begin{array}{l}\text { GHRM: an } \\
\text { investment and } \\
\text { sustainable } \\
\text { development } \\
\text { approach }\end{array}$ & $\begin{array}{l}\text { green selection and } \\
\text { recruitment, green } \\
\text { training, reward } \\
\text { system. }\end{array}$ & $\begin{array}{l}\text { Qualitative, content } \\
\text { analysis }\end{array}$ & $\begin{array}{l}\text { Results } \\
\text { identification revealed } \\
\text { development } \\
\text { and } \\
\text { of } \\
\text { chacteristics } \\
\text { of }\end{array}$ \\
\hline
\end{tabular}

\section{COnClusion \& FUture SCOPE}

Aim of this paper is to deepen the consciousness about GHRM concept. By adopting green practices firms can achieve environmental sustainability. This is only possible by effective implementation of GHRM strategies and practices within the organization. Offering Green HR practices will help in attracting skilled \& potential talents \& executing these practices will enhance employee green behaviors, green focus in the organization. There is need to provide insights about GHRM \& empirical verification. GHRM can develop motivation, social identity, commitment to employees to contribute their efforts. Green HRM efforts resulted in improved retention rate, improved public image, improved productivity \& efficiencies, improved work-life harmony, cut rates, improved labour productivity, business opportunities \& sustainable use of resources. In addition, various variables like: organizational support, environmental consciousness, employee commitment, staff participation, organizational learning capabilities and perception of employees could be used in future exploration.

\section{REFERENCES}

[1] C. J. C. Jabbour, "Environmental training in organisations: From a literature review to a framework for future research," Resources, Conservation and Recycling, vol. 74, pp. 144155, 2013.

[2] C. J. C. Jabbour, F. C. A. Santos, S. A. Fonseca, and M. S. Nagano, "Green teams: understanding their roles in the environmental management of companies located in Brazil," Journal of Cleaner Production, vol. 46, pp. 58-66, 2013.

[3] D. W. S. Renwick, T. Redman, and S. Maguire, "Green Human Resource Management: A Review and Research Agenda," International Journal of Management Reviews, vol. 15, pp. 1-14, 2013.

[4] Dutta, S. (2012). Greening people: A strategic dimension. ZENITH: International Journal of Business Economics \& Management Research, 2, 143-148.
[5] Harmon, J., Fairfield, K. D., \& Wirtenberg, J. (2010). Missing an opportunity: HR leadership and sustainability. People \& Strategy, $33,16-21$.

[6] Harvey, G., Williams, K., \& Probert, J. (2012). Greening the airline pilot: HRM and the green performance of airlines in the UK. The International Journal of Human Resource Management, $23,1-15$.

[7] J. Cherian and J. Jacob, "A Study of Green HR Practices and Its Effective Implementation in the Organization: A Review," International Journal of Business and Management, vol. 7, pp. 2633, 2012.

[8] Agarwal, S., Jindal, A., Garg, P., \& Rastogi, R. (2017). The influence of quality of work life on trust: empirical insights from a SEM application. International Journal of Indian Culture and Business Management, 15(4), 506-525.

[9] Agarwal, S., Garg, P., \& Rastogi, R. (2011). Impact of Quality of Work Life on Employee Trust. International Journal of Management Research, 54.

[10] K.-L. Wong, P. S.-H. Tan, Y.-K. Ng, and C.-Y. Fong, "The Role of HRM in Enhancing Organizational Performance," Human Resource Management Research, vol. 3, pp. 11-15, 2013.

[11] M. Mampra, "Green HRM: Does it Help to Build a Competitive Service Sector? - A Study," Tenth AIMS International Conference on Management, pp. 1273-1281, 2013.

[12] Opatha, H. H., \& Arulrajah, A. A. (2014). Green Human Resource Management: Simplified general reflections. International Business Research, 7, 101-112.

[13] P. Paille', Y. Chen, O. Boiral, and J. Jin, "The Impact of Human Resource Management on Environmental Performance: An Employee-Level Study," J Bus Ethics, 2013.

[14] Tang,G.,Chen,Y.,Jiang,Y.,Paille,P.andJia, J.(2018), “Green human resource management practices: scale development and validity", Asia Pacific Journal of Human Resources, Vol. 56 No. 1, pp.31-55.

[15] Wehrmeyer, W. (1996). Greening people: Human resources and environmental management.

[16] Zoogah,D.B.(2011), "The dynamics of green HRM behaviors: a cognitive social information processing approach", Journal of Research in Human Resource Management,Vol.25No.2,pp.117-139. 